\title{
Interdiffusion in EuS-based epitaxial superlattice nanostructures
}

\author{
A.G.Fedorov*, V.V.Volobuev, T.V.Samburskaya, A.Yu.Sipatov \\ National Technical University "Kharkiv Polytechnic Institute", \\ 21 Frunze St., 61002 Kharkiv, Ukraine \\ "Institute for Scintillation Materials, STC "Institute for Single Crystals", \\ National Academy of Sciences of Ukraine, 60 Lenin Ave., 61001 Kharkiv, \\ Ukraine
}

Received February 01, 2013

The diffusion intermixing of layers during annealing of EuS-based epitaxial superlattice nanostructures was studied by X-ray diffraction technique. The interdiffusion coefficients for EuS-PbS, EuS-PbSe, EuS-SrS superlattices were determined basing on change of the intensity of near-Bragg reflection satellites in X-ray diffraction pattern. There are no layer intermixing in EuS-PbTe superlattice was observed.

Методами рентгеновской дифракции исследованы процессы диффузионного перемешивания слоев при отжиге эпитаксиальных сверхрешеточных наноструктур на основе EuS. По изменению интенсивности рефлексов-сателлитов определены коэффициенты взаимодиффузии материалов слоев для сверхрешеток EuS-PbS, EuS-PbSe и EuS-SrS. B сверхрешетках EuS-PbTe перемешивания материалов слоев не наблюдается.

Взаємодифузія в епітаксіальних надграткових наноструктурах на основі ЕиS. О.Г.Федоров, В.В.Волобуєв, Т.В.Самбурська, А.Ю.Сіпатов.

Методами рентгенівської дифракції досліджено процеси дифузійного перемішування шарів при відпалах епітаксіальних надграткових наноструктур на основі EuS. За зміною інтенсивності рефлексів-сателітів визначено коефіцієнти взаємодифузії матеріалів шарів для надграток EuS-PbS, EuS-PbSe та EuS-SrS. У надгратках EuS-PbTe перемішування матеріалів шарів не спостерігається.

The IV-VI nanostructures open wide opportunities both for fundamental researches in the field of solid state physics [1-4], and for creation of new functional elements for microelectronics, IR-engineering and thermoelectricity $[5,6]$. The IV-VI superlattices (SL) with ferromagnetic $\left(T_{c} \sim 16 \mathrm{~K}\right)$ EuS layers are especially interesting for spintronics due to antiferromagnetic coupling between ferromagnetic layers via thin (0.5$9 \mathrm{~nm}$ ) spacers [7, 8]. For such structures with superthin layers it is very important the state of interfaces - their roughness, sharpness of transition from one layer to other, presence and size of the intermixed zones, and also temporary and temperature stability of their structure and properties. The diffusion processes in such superthin layers with a large gradient of element concentration can have the features and differences comparing with the bulk materials [9, 10]. Therefore the study of layer interdiffusion in superlattices (SL) has a great significance both in theoretical and in practical aspects.

One of the most effective methods for investigation of SL's is X-ray diffraction, which allows not only to look after processes of layer intermixing basing on the change of near-Bragg peak satellite inten- 


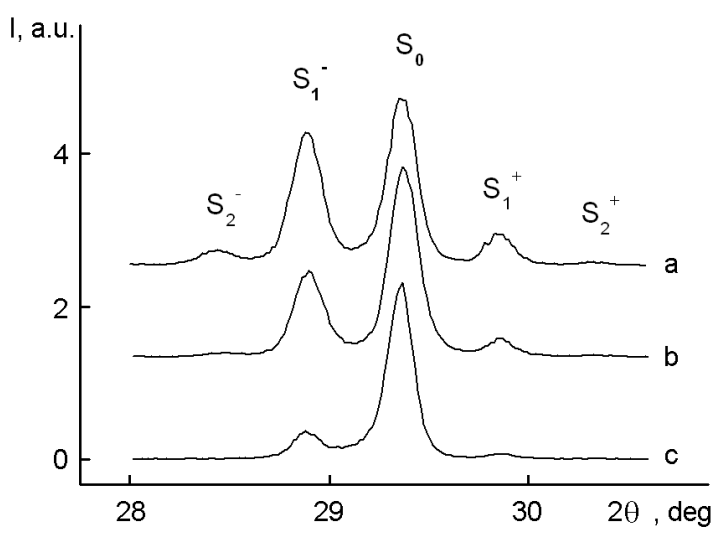

Fig. 1. X-ray diffraction curves for (200) reflection of SL EuS-PbSe with a period $20 \mathrm{~nm}$ as-deposited (a) and after annealing at temperature $733 \mathrm{~K}$ within $0.5 \mathrm{~h}$ (b) and $1.0 \mathrm{~h} \mathrm{(c)}$. $S_{k}-$ satellites.

sity but also to determine their interdiffusion coefficients [11, 12]:

$$
\operatorname{Ln}\left[I_{k}\left(\tau_{2}\right) / I_{k}\left(\tau_{1}\right)\right]=-8 k^{2} \pi^{2} D\left(\tau_{2}-\tau_{1}\right) / H^{2}
$$

where $D$ - diffusion coefficient; $H$ - period of SL; $k$ - order of satellite; $I_{k}-$ relative intensity of $k$-th satellite normalized on zero satellite intensity; $\tau$ - annealing time.

The subjects of investigation in this work are EuS-PbS, EuS-PbSe, EuS-SrS and EuS-PbTe SL's which were made in oilfree vacuum $\left(10^{-4}-10^{-5} \mathrm{~Pa}\right)$ by thermal evaporation of lead chalcogenides from tungsten boats and electron-beam evaporation of EuS and their consecutive condensation onto $(001) \mathrm{KCl}$ at $523 \mathrm{~K}$. Layer thickness and condensation speed were supervised by the calibrated quartz resonator located near a substrate. The parameters of prepared SL's are represented in Table 1. The samples were separated from the substrates by dissolution $\mathrm{KCl}$ in distillation water and were transferred onto object glasses. The structural researches (electron microscopy and X-ray diffraction) have shown that SL's have the monocrystalline

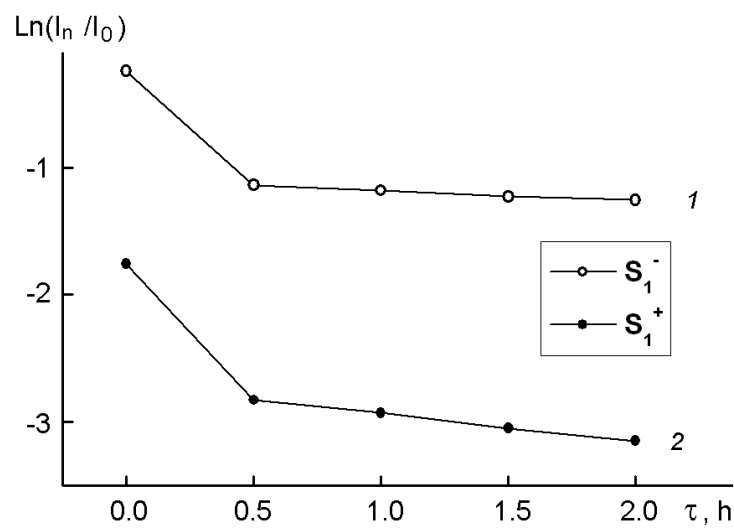

Fig. 2. Variation of satellite relative intensity for the first $S_{1}^{-}$(1) and $S_{1}^{+}$(2) order due to annealing time $\tau$ at $733 \mathrm{~K}$ for $\mathrm{SL}$ EuS-PbSe with period of $20 \mathrm{~nm}$.

layers in (001) orientation with sharp interfaces. This indicated by the presence of satellites of the 2 -rd order in the X-ray diffractions (Fig. 1a). The samples were annealed in vacuum at three different temperatures for each SL's (see Table 2). The samples were taken out from the vacuum chamber periodically for X-ray diffraction examinations. Diffraction curves were taken using a double-crystal spectrometer in $\mathrm{Cu}-\mathrm{K} \alpha_{1}$ radiation and $\varphi-2 \varphi$ scanning regime $((400)$ reflection of the silicon monochromator crystal was used). In Fig. 1 it is seen that during an annealing of SL EuS$\mathrm{PbSe}$ the intensity of lateral satellites decreases and central (zero) satellite increases indicating intermixing of the layers. More evidently process of layer intermixing in SL EuS-PbSe at $733 \mathrm{~K}$ is submitted in Fig. 2, from which it is visible, that there are two stages of diffusion - the fast (on the initial stages of annealing) and the slow one. The fast diffusion on the initial stages of annealing is evidently due to the presence of nonequilibrium nonstoichiometric point defects in lead chalcogenides [13].

The similar dependences of satellite intensity changes are observed at temperatures $593 \mathrm{~K}$ and $693 \mathrm{~K}$.

Table 1. Parameters of the samples: $f$, is the lattice misfit of layers; $N$, number of layers; $H$, the SL period.

\begin{tabular}{|c|c|c|c||}
\hline SL & $f, \%$ & $N$ & $H, \mathrm{~nm}$ \\
\hline EuS-PbS & 0.5 & 20 & $8.0 ; 12.0 ; 18.0$ \\
EuS-PbSe & 2.5 & 20 & $11.6 ; 19.0 ; 20.0$ \\
EuS-PbTe & 7.7 & 20 & $10.2 ; 12.0 ; 16.2$ \\
EuS-SrS & 0.8 & 20 & $10.0 ; 12.4 ; 16.0$ \\
\hline
\end{tabular}


Table 2. Diffusion characteristics of SLs: $H$, the SL period; $T$, the annealing temperature; $D$, diffusion coefficient; $D_{0}$, pre-exponential factor; $E_{a}$, activation energy; $D_{523} \mathrm{~K}$, diffusion coefficient at $523 \mathrm{~K} ; \Delta X$, the intermixed zone thickness at $523 \mathrm{~K}$ for $1 \mathrm{~h}$

\begin{tabular}{|c|c|c|c|c|c|c|c|}
\hline $\mathrm{CL}$ & $H, \mathrm{~nm}$ & $T, \mathrm{~K}$ & $D, \mathrm{~cm}^{2} / \mathrm{s}$ & $D_{0}, \mathrm{~cm}^{2} / \mathrm{s}$ & $E_{a}, \mathrm{eV}$ & $\begin{array}{c}D_{523 \mathrm{~K}} \\
\mathrm{~cm}^{2} / \mathrm{s}\end{array}$ & $\Delta X, \mathrm{~nm}$ \\
\hline \multirow[t]{3}{*}{ EuS-PbS } & 8.0 & 543 & $1.1 \cdot 10^{-20}$ & \multirow[t]{3}{*}{$2.2 \cdot 10^{-9}$} & \multirow[t]{3}{*}{1.22} & \multirow[t]{3}{*}{$3 \cdot 10^{-21}$} & \multirow[t]{3}{*}{0.06} \\
\hline & 12.0 & 593 & $6.4 \cdot 10^{-20}$ & & & & \\
\hline & 18.0 & 623 & $1.7 \cdot 10^{-18}$ & & & & \\
\hline \multirow[t]{3}{*}{ EuS-PbSe } & 19.0 & 593 & $7.7 \cdot 10^{-21}$ & \multirow[t]{3}{*}{$4.0 \cdot 10^{-10}$} & \multirow[t]{3}{*}{1.26} & \multirow[t]{3}{*}{$2.9 \cdot 10^{-22}$} & \multirow[t]{3}{*}{0.02} \\
\hline & 11.6 & 693 & $3.3 \cdot 10^{-19}$ & & & & \\
\hline & 20.0 & 733 & $8.7 \cdot 10^{-19}$ & & & & \\
\hline \multirow[t]{3}{*}{ EuS-SrS } & 12.4 & 673 & $6.2 \cdot 10^{-21}$ & \multirow[t]{3}{*}{$1.7 \cdot 10^{-8}$} & \multirow[t]{3}{*}{1.3} & \multirow[t]{3}{*}{$3.2 \cdot 10^{-19}$} & \multirow[t]{3}{*}{0.7} \\
\hline & 10.0 & 723 & $4.5 \cdot 10^{-20}$ & & & & \\
\hline & 16.0 & 773 & $1.1 \cdot 10^{-18}$ & & & & \\
\hline
\end{tabular}

The layer interdiffusion coefficients for SL EuS-PbSe were determined for each temperatures using expression (1):

$$
\begin{gathered}
D=7.7 \cdot 10^{-21} \mathrm{~cm}^{2} / \mathrm{s}(593 \mathrm{~K}) ; \\
3.3 \cdot 10^{-19} \mathrm{~cm}^{2} / \mathrm{s}(693 \mathrm{~K}) ; \\
8.7 \cdot 10^{-19} \mathrm{~cm}^{2} / \mathrm{s}(733 \mathrm{~K}) .
\end{gathered}
$$

Taking into account the Arrhenius law $\left(D=D_{0} \exp \left(E_{a} / k T\right)\right)$, the values of activation energy $E_{a}$ and pre-exponential coefficient $D_{0}$ were determined for SL EuS-PbSe:

$$
D_{0}=4.0 \cdot 10^{-10} \mathrm{~cm}^{2} / \mathrm{s} ; \quad E_{a}=1.26 \mathrm{eV} .
$$

Thus it is possible to calculate the diffusion coefficient for any necessary temperature (for-example, for SL growth temperature $523 \mathrm{~K}$ ) and to estimate the intermixing zone $\Delta X$ formed during SL growth time $(t \sim$ $1 \mathrm{~h})$ :

$$
\Delta X^{2} \sim 4 D t .
$$

The results of such calculations for SL EuS-PbSe are $D_{523} \mathrm{~K}=2.9 \cdot 10^{-22} \mathrm{~cm}^{2} / \mathrm{s}$; $\Delta X=0.02 \mathrm{~nm}$.

The same procedure was performed for SL EuS-PbS and EuS-SrS and the results of investigations are presented in Table 2.

It should be noted that layer materials in SL EuS-PbTe are not intermixed up to $800 \mathrm{~K}$ until re-evaporation of materials was observed.
The results are presented in Table 2. Basing of the results the SLs studied are considered to be rather stable structures having in as-prepared state very small intermixed zone thickness of the order of one monolayer or less, thus being very promising objects for further studies and applications.

\section{References}

1. K.H.Herrmann, J.Auth, K.P.Mollmann et al., Semicond. Sci. and Technol., 8, 176 (1993).

2. V.N.Lytskii, V.A.Petrov, A.S.Rylik et al., Phys.Low-Dim. Struct., 7, 37 (1994).

3. N.Ya.Fogel, A.S.Pokhila, Yu.V.Bomze et al., Phys. Rev. Lett., 86, 512 (2001).

4. A.Stachow-Wojcik, T.Story, W.Dobrowolski et al., Phys. Rev. B, 60, 15220 (1999).

5. D.L.Partin, Appl. Phys. Lett., 45, 487 (1984).

6. K.Biswas, J.He, I.D.Blum et al., Nature, 489, 414 (2012).

7. H.Kepa, J.Kutner-Pielaszek, J.Blinowski et al., Europhys. Lett., 56, 54 (2001).

8. H. Kepa, C. F. Majkrzak, A. Sipatov et al., J. Phys.: Condens. Mater., 21, 124207 (2009).

9. G.E.Henein, J.E.Hilliard, J.Appl.Phys., 55, 2895 (1984).

10. D.K.Arch, J.P.Faurie, J.-L.Staudenmann et al., J.Vac.Sci.Technol., A4, 2101 (1986).

11. H.Krenn, E.Koppensteiner, A.Holzinger et al., J.Appl.Phys., 72, 97 (1992).

12. A.G.Fedorov, I.A.Shneiderman, A.Yu.Sipatov et al., Functional Materials, 5, 52 (1998).

13. V.Leute, H.Bottner, H.Schmidtke, Zeitschrift fur Naturforschung, 34a, 89 (1978). 